\title{
Latin datives with prefixed verbs and beyond: A view from the theory of applicatives
}

\author{
Víctor Acedo-Matellán \\ University of Cambridge. Queens' College \\ va285@cam.ac.uk
}

Received: February 26, 2017

Accepted: July 17, 2017

\begin{abstract}
I discuss the syntax and semantics of dative DPs with a spatial (Ground) interpretation, focusing on those dependent on prefixed verbs, in Early and Classical Latin. I assess and discard the two main previous approaches: the one in which the dative realizes an argument of the preverb (its Ground) and the one in which it corresponds to a benefactive/malefactive dative. I propose an analysis whereby the dative is introduced by an applicative head below the eventive head. In the case of predicates headed by a prefixed verb, I assume that the preverb originates in an embedded PP that involves a null nominal of relational semantics. Being under the scope of the dative, the nominal can be interpreted as inalienably possessed by its referent, whence the inference that the dative identifies the Ground of motion. A felicitous prediction is that the spatial dative should not be licensed by unprefixed manner-of-motion verbs, since they do not encode a resulting location.
\end{abstract}

Keywords: applicatives; argument structure; change-of-location predicates; change-of-state predicates; dative; event structure; Latin; PP; prefixed verbs; preverbs

Resum. Els datius del llatí amb verbs prefixats i més enllà: una aproximació des de la teoria dels aplicatius

Tracto de la sintaxi i la semàntica dels SPs en datiu que presenten una interpretació espacial (de Fons), tot concentrant-me en aquells que depenen de verbs prefixats, en llatí arcaic i clàssic. Avaluo i descarto els dos principals enfocaments anteriors: aquell en què el datiu expressa un argument del preverb (el seu Fons) i aquell en què correspon a un datiu benefactiu o malefactiu. Proposo una anàlisi en què el datiu és introduït per un nucli aplicatiu situat per sota del nucli esdevenimental. En el cas dels predicats encapçalats per un verb prefixat, assumeixo que el preverb s'origina dins un SP que conté un nom abstracte de semàntica relacional. Com que és dins

* I wish to express my gratitude to Jaume Mateu and Renato Oniga, editors of this volume. Versions of this work were presented in the 25th Colloquium on Generative Grammar, IKER (Center for the Study of the Basque Language and its Texts (UMR 5478)), Baiona (Basque Country), 21-23 May 2015, and in the workshop Dative structures and beyond, Centre de Lingüística Teòrica Universitat Autònoma de Barcelona (Catalonia), 26-27 January 2017. I thank their audiences for useful comments. The paper has greatly benefitted from the remarks and suggestions provided by two anonymous reviewers and by Jaume Mateu. All errors remain of course my own. This research has been partly funded by Ministerio de Economía y Competitividad (Spain) and the European Regional Development Fund through the project FFI2014-56968-C4-1-P (VARINLEXSIN, 'Variation in the lexicon-syntax interface'). 
de l'abast del datiu, aquest nom pot ser interpretat com posseït inalienablement pel seu referent, d'on emergeix la inferència que el datiu identifica el Fons de moviment. Una predicció reeixida és que el datiu espacial no és legitimat per verbs de manera de moviment no prefixats, atès que no codifiquen una localització resultant.

Paraules clau: aplicatives; estructura argumental; predicats de canvi de lloc; predicats de canvi d'estat; datiu; estructura esdevenimental; llatí; preverbs; SP; verbs prefixats

\section{Table of Contents}

1. Introduction

2. P-datives: their properties and their relationship with directional datives

\section{Previous approaches}

4. The p-dative as an applied argument
5. Predictions. Extension of the analysis to other datives and to unprefixed verbs

6. Conclusions and remaining issues References

\section{Introduction}

Among the syntactic issues related to the dative case in Latin, its spatial interpretation, specifically that related to the use of prefixed verbs, has been a particularly amply debated one in the Latin linguistics tradition. ${ }^{1}$ Consider for instance the following example: ${ }^{2}$
(1) Aggeri ignem in-ferebant.
rampart.DAT fire.ACC in-carry.IPFV.3PL
(Caes. Gall. 7, 22, 4)
'They were carrying fire against the rampart.'

The dative DP aggeri 'the rampart' is interpreted as an argument of the preverb or prepositional prefix in- 'in, against', specifically, as its Ground (Talmy 1978, 2000; relatum, in Lehmann's 1983 terminology). Thus, the fire is brought against the rampart. Since the dative, unlike the accusative and the ablative, is not selected by any preposition, it is not clear what is licensing this case and where the Ground interpretation comes from. For convenience, I will refer to this type of dative, interpreted as the Ground of a preverb, as $p$-dative.

As mentioned above, the predilection of prefixed verbs for dative complements has not gone unnoticed to scholars of Latin. Fay (1911: 194) reports that "[Quintilian] seems to hint (IX. 3, 1) that the dative with this group was a productive and growing construction" and Fay (1911: 187), Lease (1912: 285) and Nutting (1921: 368) point out, and also fight against, the enshrinement of the selection of a dative by prefixed

1. See Gutiérrez Galindo (2004) for a recent historical review of the theories on the dative case in Latin.

2. If not otherwise indicated, the Latin examples and their citation form have been taken from the Bibliotheca Teubneriana Latina (2009). The English translations are my own, if I do not indicate any specific translator. 
verbs as a kind of rule in Latin grammars. ${ }^{3}$ Lehmann (1983: 157) observes that "the frequency and even regularity of the dative expressing the relatum of certain preverbs is difficult to account for." Along the same lines, Serbat (1996: 534) emphasizes, with respect to the case of the preverb in- 'in', that while many simple verbs never appear with a dative, their in-prefixed counterparts very frequently do so. All in all, most grammars and syntax treatises dedicate special remarks and even a special section to p-datives. ${ }^{4}$

There have been basically two approaches to p-datives. In the one entertained by Lehmann (1983) and, in part, Serbat (1996: 443 ff.), the dative encodes a semantic argument of the preverb: its Ground. On the other hand, in the approach found in Rubio (1982: 150) or Théoret (1982: 91), the p-dative is a case of a benefactive (or malefactive) dative - dativus (in) commodi. In any case, there has been to my knowledge no attempt at providing a configurational analysis of this type of dative. ${ }^{5}$ In this work, which can be considered an expansion of remarks in Acedo-Matellán (2016: 96-100), I provide such an analysis, based on a combination of Cuervo's (2003) and Pylkkänen's (2008) theories of applicative heads, Noonan's (2010) and Terzi's (2010) analysis of locative PPs and a derivational theory of verbal prefixation in Latin (Miller 1993, Oniga 2005, Acedo-Matellán 2006, 2016). I claim that these datives are neither governed by the preverb nor equivalent to benefactive datives, although my analysis explains why the dative is interpreted both as the Ground of the preverb and as an affected entity. In particular the dative is introduced by an applicative head akin to Cuervo's (2003: 121) Affected Applicative, and is interpreted as related to a null nominal of relational semantics embedded in a PP where the preverb originates. The dative refers to an entity inalienably possessing the region of space denoted by the set of preverb plus null nominal, and, inferentially, as the Ground of the preverb - see (34) for the full analysis.

Although I concentrate primarily on p-datives, my analysis aims at explaining other similar uses like the directional one with unprefixed verbs, the dativus sympatheticus and the use of the dative with verbs of change of state like miscere 'mix'. The analysis could in principle be extended to stative verbs, although for space reasons I cannot explore this possibility in the present paper (see footnote 26).

The structure of the article is as follows. In section 2, I present the main features of constructions with p-datives, and I put them in relation with constructions involving a directional dative. In section 3, I revise and discard the two main previous approaches.

3. The rule was initiated by F. Schultz, according to Pinkster (2011: 128). In relation to Quintilian's observation, Romance has retained the use of the dative with a spatial interpretation, as an anonymous reviewer rightly remarks and as will become clear in later sections. For reasons of space, I cannot expand on this issue.

4. See Bennett (1910-1914: 122-132), Kühner \& Stegmann (1912: 325-326), Woodcock (1959: 44-45), Ernout \& Thomas (1964: 69), Hofmann \& Szantyr (1965: 87-91), Touratier (1994: 223), Rubenbauer, Hofmann \& Heine (1995: 139-141), Serbat 1996 (439-461, 512-544, 546-562) and Pinkster (2015: 106-107), among others.

5. In Devine \& Stephens's (2013: 136-137) formal semantic analysis different attachment sites are proposed for three different kinds of datives: a low benefactive, a mid benefactive and a high benefactive (the ethical dative). However, these authors are not concerned with the specific case of p-datives. 
In section 4, I put forth my analysis. Section 5 explores the predictions of this analysis, extending it to the use of the dative in constructions not featuring a prefixed verb. Section 6 concludes and points out the remaining challenges.

\section{P-datives: their properties and their relationship with directional datives}

Prefixed verbs heading constructions of directed motion have been observed to appear especially frequently with a dative DP interpreted as the Ground:

(2) Tibi ad-duxi hominem. you.DAT at-lead.PRF.1SG person.ACC 'I have brought the man to your presence.' (Plaut. Most. 804)

(3) [Rostrum lupi] portis prae-figunt. muzzle.ACC wolf.GEN door.DAT.PL before-fasten.3PL 'They fasten a wolf's muzzle before the doors.' (Plin. nat. 28, 157, 18)

(4) [Spinae] corpori ex-trahuntur felis excrementis. thorn.NOM.PL body.DAT out-drag.PASS.3PL cat.GEN excrement.ABL.PL 'Thorns are extracted from the body with a cat's excrements.'

(Plin. nat. 28, 245, 19)

Consider (2). In this example the dative tibi 'you' is interpreted as the Ground with respect to the preverb ad- 'at, beside', as shown in the English translation 'to your presence', "to the presence of you". The Ground interpretation is the defining characteristic of p-datives, and is made particularly evident by the fact that, as shown by Serbat (1996: $512 \mathrm{ff}$.), there are verbs that can only take a spatial dative argument when prefixed, such as currere 'run' or trudere 'push' (Serbat 1996: 507). Other unprefixed, directional verbs like ruere 'rush, fall violently' may take a directional dative (see below), but only do so in poetry (Serbat 1996: 506).

Alongside its interpretation as Ground, the dative licenses an affected interpretation that is made evident when the p-dative is compared to a Ground expressed in the form of a PP:

(5) [Cunila sativa] in potione a-spersa.

Cunila.NOM cultivated.NOM in drink.ABL at-sprinkled.NOM.F.SG

'Cultivated cunila sprinkled in a drink.' (Plin. nat. 20, 173, 18)

(6) Pecori=que a-spergere uirus.

cattle.DAT=and at-sprinkle.INF venom.ACC

'And sprinkle the cattle with venom.'

(Verg. georg. 3, 416)

According to Devine \& Stephens (2013: 134), “[t]he dative [...] suggests that the ill effects of the poison are directed at the flock [...], while the locative [...] 
just denotes the place where the substance is sprinkled." See also Ernout \& Thomas (1964: 69), Rubio (1982: 150) and Pinkster (2011). ${ }^{6}$

The previous feature has probably induced many scholars to highlight the fact that p-datives most frequently refer to an animate being, as in (2) - see, for instance, Kühner \& Stegmann (1976: 307-341). However, this is not necessarily the case, as shown elsewhere and in (7) below, a prose example — see also Ernout \& Thomas (1964: 69):

(7) Hi duo amnes [...] in-cidunt Oriundi flumini. these.NOM two.NOM river.NOM.PL in-fall.3PL Oriuns.DAT river.DAT 'These two rivers fall into the river Oriuns.' (Liv. 44, 31, 4)

One last characteristic of the construction at hand is that not all preverbs select datives with the same regularity. Lease (1912: 287) provides percentages of use of the dative with each preverb, in several authors from different periods. He shows, for instance, that while verbs prefixed with super- 'above, over' are used with a dative in $52.6 \%$ of the cases, those prefixed with circum- 'around' select the dative only in $4.9 \%$ of the cases. Lehmann (1983: $155 \mathrm{ff}$.) has probably dwelt on this question most extensively, and, in addition to providing new generalizations on the relationship between the preverbs and the dative, attempts to furnish an explanation for these frequency effects (see next section).

The debate on the appearance of a dative "argument" with prefixed verbs has been parallel to the one on the directional dative, i.e., the dative as expressing goal of motion. ${ }^{7}$ Perhaps the most famous example in this latter debate is the following one:

(8) It clamor caelo. go.3SG cry.NOM heaven.DAT 'The cry went up to heaven.'
(Verg. Aen. 5, 450)

(Translation from Van Hoecke 1996: 11)

This use of the dative has also been the topic of a time-honoured discussion. Thus, Murru (1978) points out that already the Roman grammarian Servius (Serv. GLK IV p. 433, apud Murru 1978: 144) justified the term octavus casus "eighth case" to label the dative in its directional use, on the basis of the example in (8). Contemporary scholars have participated in this discussion, and grammars and syntax treatises also dedicate a section to the directional dative. ${ }^{8}$ Although it seems that the directional dative - at

6. For similar remarks on the difference between constructions involving a dative goal and a prepositional goal in Spanish, see Demonte (1995) and Cuervo (2003).

7. I use the term directional dative following Scherer's (1975: 49) Dativ der Richtung and Echarte's (1994) and Baños Baños's (2009: 199) dativo de dirección.

8. See Gustafsson (1904), Fay (1911), Löfsted (1928-1933), Murru (1978), Colucci (1981), Bonelli (1983), Echarte (1994), Van Hoecke (1996), Cabrillana (1997a, b) and Van Langendonck (1998), among others, and the remarks found in grammars and syntax treatises such as Woodcock (1959: 39-40), Ernout \& Thomas (1964: 69-70), Scherer (1975: 49), Touratier (1994: 223), Serbat (1996: 505-544), Baños Baños (2009: 199-200), Calboli (2009: 100-104) and Pinkster (2015: 813-814). 
least that selected by the verb ire 'go' - is restricted to poetry and may be mimicking a Greek syntactic use (see Pinkster 2015: 813-814 and references therein), in section 5.3, I will argue that it can be generated by the grammar in the same way as the p-dative.

\section{Previous approaches}

\subsection{P-datives as actually encoding the Ground of the preverb}

One of the approaches to the nature of p-datives is that represented by Lehmann (1983), who argues that the preverb may take its relatum (= Ground) in the dative. This author thus considers that the $\mathrm{p}$-dative is really implementing a semantic (internal) argument of the preverb. ${ }^{9}$ The other possible cases for the Ground DP are the ones governed by the prepositional counterpart of the preverb: the accusative and the ablative. In this respect, Lehmann (1983: 153) points out that "[a] preverb has rection and governs its relatum [= Ground; VA] when this depends on the verbum compositum in the case which it would have to take if the preverb were a preposition". Accusative and ablative DP Grounds are illustrated in (9) and (10), respectively:

(9) Istum circum-duce has $=$ ce aedis. that.M.ACC around-bring.IMP.2SG this.ACC.F.PL=here house.ACC.PL 'Take that person round this house.' $\quad$ (Plaut. Most. 843)

(10) $[$ Metellus] monte de-scenderat. Metellus.NOM mountain.ABL downward-climb.PLUPRF.3SG

'Metellus had climbed down from the mountain.' (Sall. Iug. 50, 2, 22)

Lehmann (1983) capitalizes on the fact, noted in the previous section, that different preverbs "select" a dative with very different frequencies. In particular, he claims that "those preverbs most intimately associated with the ablative, most bluntly reject the dative" (Lehmann 1983: 157). He explains this fact, and the use of p-datives in general, on the grounds of a filter on double accusatives in Latin. The Ground of the preverb preferably emerges in the dative in those cases in which two accusative DPs would otherwise concur, namely, when a) due to the nature of the prefixed preposition the Ground should emerge in the accusative, and b) the base verb is transitive, bringing an additional accusative into the predicate. From this perspective, the use of the dative foribus 'doors' in (11) prevents the generation

9. Pinkster (2011) also links the presence of the dative to preverbation itself, but he puts forth an explanation in which the p-dative is justified on the grounds of the membership of the prefixed verb that selects it in some semantically defined class of dative-taking verbs. As an anonymous reviewer points out, one may wonder how such a theory can account for contrasts such as that between (5) and (6), involving the same prefixed verb. In Pinkster (1988), he provides a different, diachronic explanation for intransitive prefixed verbs selecting a dative: the p-dative originated as a benefactive adjunct (a "dative of interest") but eventually came to occupy a slot in the subcategorization frame of the verb. 
of the otherwise anomalous sentence of (12), in which the goal of the argument of the preverb in- 'in, into' has been left in the accusative (fores): $\begin{array}{lll}\text { (11) Foribus nomen sum } & \text { in-scribere. } \\ \text { door.DAT.PL name.ACC } & \text { his.ACC.N.SG } & \text { in-write.INF } \\ \text { 'To write his name on the door.' } & \end{array}$

(12) *Fores nomen suum in-scribere. door.ACC.PL name.ACC his.ACC.N.SG in-write.INF

Thus, for Lehmann (1983) the p-dative somehow boils down to a rescue strategy: it marks otherwise accusative arguments that cannot emerge in the accusative, as per the mentioned filter, or in the ablative (since they do not encode sources). When the Ground corresponds to a source, as opposed to a goal, the ablative is always available and this would be why, according to this author, preverbs corresponding to ablative-governing prepositions do not take dative Grounds. The case is, however, that p-datives are not rare with preverbs corresponding to ablative-taking prepositions, as pointed out by Serbat (1996: 546); consider, for instance, (4) and the next example, and many other ones in Serbat's (1996) work: ${ }^{10}$

(13) Larici [...] umor de-fluit.

larch.DAT liquid.NOM downward-flow.3SG

'From the larch a liquid substance flows down.' (Plin. nat. 16, 194, 3)

Even if cases like the one above were few, their existence could not be compatible with the grammatical explanation put forth by Lehmann - the double accusative filter. In any case, this filter should be qualified if we want to account for cases like (9) or double object constructions akin to the ones found in English:

(14) Peior magister te istaec docuit.

worse.NOM teacher.NOM you.ACC this.ACC teach.PRF.3SG

'A worse teacher taught you this.' (Plaut. Bacch. 163)

Other shortcomings affect Lehmann's (1983) hypothesis, to which Serbat's (1996) theory of the dative could be said to come close in spirit — cf. for instance his schemas on p. 443 and 448. The most evident one is that Ground DPs in the dative would be the only ones in which case assignment could not be directly linked to the preverb, since, as pointed out in section 1, no preposition in Latin assigns this case. Moreover, since the p-dative is, according to Lehmann's view, realizing the preverb's internal argument, the affectedness effect observed to emerge with the dative, but not with objects of prepositions (see previous section), also remains unaccounted for. Finally, if a unified explanation for $\mathrm{p}$-datives and directional

10. In this use, the dative has been frequently referred to as dative of separation (Rubio 1982: 150, García Hernández 1986: 245). 
ones is desirable, it does not seem feasible under the assumption that the p-dative is a rescue strategy for Ground DPs that would otherwise take accusative due to the preverb.

\subsection{The p-dative as a dativus (in)commodi}

Proponents of the other major approach to the dative used in the expression of directionality, with and without prefixed verbs, consider it a case of benefactive/malefactive dative, a dativus (in) commodi. Rubio (1982: 150), for instance, takes these datives, as all datives, to design the entity "interested" in the situation described by the verb:

(15) Silici scintillam ex-cudit. stone.DAT sparkle.ACC out-beat.3SG

'He beat a sparkle out of the stone.'

(Verg. Aen. 1, 174)

For this author the dative silici 'stone' is humanized: the stone is robbed of the sparkle. In no case does the dative indicate the source, since the directionality is exclusively encoded by the verb excudit (see also García Hernández 1995: 44). Similarly, Théoret (1982: 91) takes datives with verbs like ad-ferre "at-bring" and au-ferre "away-bring" to be examples of dativi (in)commodi:

(16) Exoptatum inimico nuntium [ad-ferret].

desired.ACC enemy.DAT message.ACC at-bring.IPFV.SBJV.3SG

'He would bring the desired message to the enemy.' (Sex. Rosc. 19)

This hypothesis does not have to rely on the ban on two accusatives that is at the base of Lehmann's (1983) account of p-datives, so it spares us of the problems that ban involves. The hypothesis also allows a single explanation for $\mathrm{p}$-datives and the datives with other motion verbs, and it straightforwardly explains the affectedness effect on the dative, not necessarily present in Ground DPs that are objects of prepositions. All in all, it seems that the view represented by Rubio (1982) is more promising than that represented by Lehmann (1983). However, I think that there is more to say about p-datives than just lumping them together with all the datives of interest. First of all, the interpretation of the $\mathrm{p}$-dative as being the Ground of the preverb seems undeniable and has to be accounted for. Take, for instance, the following example:

(17) Gallinis anitum ova saepe sup-ponimus.

hen.DAT.PL duck.GEN.PL egg.ACC.PL often under-put.1PL

'We often place ducks' eggs beneath the hens.' (Cic. nat. deor. 2, 124)

In this example the preverb sub- 'under' denotes an "under" region and that region is interpreted as the under region of the hens, as read off the dative DP gallinis 'hens'. 
Moreover, there are reasons to think that the p-dative is not exactly the same as a dativus (in) commodi. First there are certain prose cases where it is hard to argue for such an interpretation, as in (7) above, repeated below: ${ }^{11}$

(18) $\mathrm{Hi}$ duo amnes [...] in-cidunt Oriundi flumini. these.NOM two.NOM river.NOM.PL in-fall.3PL Oriuns.DAT river.DAT 'These two rivers fall into the river Oriuns.' (Liv. 44, 31, 4)

Second, there are predicates headed by a prefixed verb and involving a dative that is interpreted as a dativus (in)commodi but clearly not as the Ground of the preverb:

(19) Ex-suscitate uostram huc custodem mihi.

out-wake.IMP.2PL your.ACC.F.SG here portress.ACC me.DAT

'Arouse your portress for me and send her here.' (Plaut. Curc. 91)

(20) Tibi argentum iubebo [...] ec-ferri foras.

you.DAT money.ACC order.FUT.1SG out-bring.INF.PASS outside

'I will have the money brought out for you.' (Plaut. Bacch. 93)

Finally, while the dativus (in)commodi is related to the event as a whole (Serbat 1996: 438, Baños Baños 2009: 203), there is evidence that the p-dative is not. Admittedly, this evidence rests on the passive competence of a nonnative speaker. ${ }^{12}$ Specifically, Happ (1976), who develops diagnostic tests for constituency in Latin, claims that the p-dative cannot be stranded under id facio $=$ 'do-so' substitution:

(21) a. [Rex] capillum sibi e-vellit. king.NOM hair.ACC himself.DAT out-pluck.3SG

'The king plucks out his hair.' $\quad$ (Tusc. 3, 62; apud Happ 1976: 407)

b. *Rex capillum e-vellit et id facit sibi. king.NOM hair.ACC out-pluck.3SG and it.ACC make.3sG himself.DAT Int. 'The king plucked the hair and he did it to himself.'

Assuming that the id facio proform replaces verbal phrases, the ungrammaticality that Happ (1976: 407) claims for (21b) would indicate that the p-dative sibi 'himself' is merged inside that phrase and thus is not related to the event as a whole. In that respect this dative contrasts with a benefactive dative such as the one in the next example, which, according to this author, does admit stranding:

11. For a non-directional interpretation of similar examples see Gutiérrez Galindo (1995: 54-55).

12. See Pfister (1983) or Miller (1993) for arguments in favour of the use of nonnative competence in Latin. 
(22) a. Hanc mihi dispensationem deposco.

this.ACC me.DAT management.ACC claim.1sG

'I claim the management of this matter for myself.'

(Phil. 13, 11; apud Happ 1976: 405)

b. Hanc dispensationem deposco et id facio mihi.

this.ACC management.ACC claim.1SG and it.ACC make.1SG me.DAT

'I claim the management of this matter and I do it for myself.'

In sum, there are some significant differences between p-datives and benefactive/malefactive datives. Moreover, the Ground interpretation of the p-dative has to be explicitly integrated in this view.

In the next section I will argue for a configurational analysis aiming at accounting for the features of the construction at hand and overcoming the disadvantages of the previous analyses.

\section{The p-dative as an applied argument}

In this section I provide an analysis of p-datives. I initially follow an idea in Oya (2009), who analyses certain predicates in German featuring the particle $z u$ 'to' and a dative interpreted as goal of motion:

(23) Ich warf dem Kind den Ball zu.

I threw the.DAT child the.ACC ball to

'I threw the ball to the child.'

(German; Oya 2009: 266)

Oya, following Olsen (1997), argues that, although interpreted as a Ground, the dative dem Kind 'the child' is higher than the Figure argument den Ball 'the ball'. He claims, specifically, that the dative is interpreted as the possessor of a null nominal in the complement of $z u$ 'to'. This nominal, which is the real (syntactic) goal argument, has relational semantics and denotes something like "THE BODY OF". The dative is interpreted as the Ground of $z u$ 'to' as an effect of its being the possessor of this null nominal. I use Oya's (2009) idea but I generalize the semantics and the function of the null nominal to all PPs.

I assume an articulated approach to the representation of argument and event structure, as in Acedo-Matellán (2016), following the tradition of Hale \& Keyser $(1993,2002)$ and Mateu (2002). The more specific assumptions for the present analysis are the next ones:

1) The preverb originates as a preposition in a vP-internal PP codifying the Ground (Miller 1993, Oniga 2005, Acedo-Matellán 2016, among others).

2) Following Terzi's $(2007,2010)$ and Noonan's (2010) theories, locative PPs involve an abstract locative nominal of relational semantics, here called Locus, denoting the region of space occupied by the Ground.

3) The p-dative is the specifier of an applicative head akin to Cuervo's (2003: 121 ff.) Affected Applicative, relating an entity with a (resulting) location/state. 
The p-dative may provide reference to Locus; specifically, the latter may be interpreted as being inalienably possessed by the former, whence the inference that the p-dative identifies the Ground of the preverb.

I elaborate on these three assumptions in sections 4.1, 4.2 and 4.3, respectively, and I implement them in the analysis in section 4.4.

\subsection{Preverbs as prepositions/particles}

In works like Miller (1993: 121-126), Oniga (2005: 216-221) or Acedo-Matellán (2016: 67) it is proposed that Latin preverbs, which largely correspond to prepositions, ${ }^{13}$ are indeed adpositional elements embedded in the $\mathrm{vP}$ at some level of analysis, and that they end up affixed to the verb. ${ }^{14}$ An analysis along those lines of example (10) is shown below:

(24) [Metellus] monte de-scenderat.

Metellus.NOM mountain-ABL downward-climb.PLUPRF.3SG

'Metellus had climbed down from the mountain.' (Sall. Iug. 50, 2, 22)

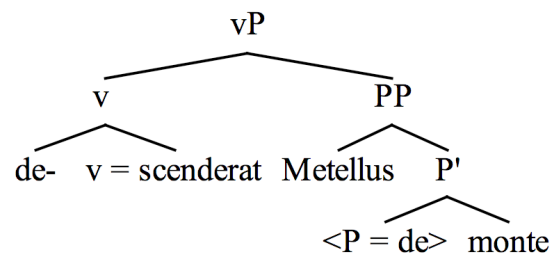

In the above tree the prefix $d e$ - 'downward' is originated as a preposition heading its own PP, which is embedded under the eventive head v. The PP articulates a Figure-Ground schema (Talmy 1978, 2000, Svenonius 2007), Metellus conveying the Figure of movement and the ablative monte 'the mountain' conveying the Ground. The whole configuration is an unaccusative one, since it lacks an external argument, the $\mathrm{v}$ head being interpreted as a GO/BECOME operator. ${ }^{15}$ That is why the Figure argument emerges in the nominative. Finally, a prefixation operation takes de from is base position (represented in angle brackets) and brings it onto the verb, producing the prefixed form descenderat.

Acedo-Matellán (2016: 89) shows that prefixed verbs in Latin often appear in the absence of their Ground arguments (cf. monte 'the mountain' in the last example), importantly, with no impact on the event structure properties of the predicate: ${ }^{16}$

13. Exceptions are dis- 'asunder, apart' and se- 'away from', which, at least in Classical Latin, do not surface as prepositions.

14. Cf. also Svenonius (2004), Biskup (2009) and Acedo-Matellán (2016), among others, for Slavic.

15. See Acedo-Matellán (2016: 105-109) for evidence that constructions headed by prefixed motion verbs in Latin are unaccusative.

16. See, for a similar claim regarding Slavic and Ancient Greek, Spencer \& Zaretskaya (1998) and Acedo-Matellán (2016: 219-221), respectively. 
(25) In equo vehens venit

in horse.ABL drive.PTCP.NOM.M.SG come.PRF.3SG

neque de-scendere voluit.

and not downward-climb.inf want.prf.3sg

'He came on the horse and did not want to get down.' (Gell. 2, 2, 13)

In cases such as this one, preverbs behave similarly to Germanic particles, which many authors have described as intransitive prepositions (see Emonds 1972, Kayne 1985, Svenonius 2003, among others). The difference in the analysis with respect to the example in (24) would be the existence of a null DP in Ground position, here anaphorically identified with equo 'horse'.

\subsection{The structure of spatial PPs}

The second important factor in my analysis of p-datives has to do with the structure of PPs encoding spatial relations.

I first note that I follow a line of analysis from Jackendoff (1983) through Koopman (2000), Svenonius (2007, 2010) and den Dikken (2010), among others, in assuming two different abstract prepositions for the articulation of directional and stative notions: Path and Place, respectively. In particular, locative denotations correspond to a PlaceP and directional ones correspond to a PathP, which in turn embeds a PlaceP:

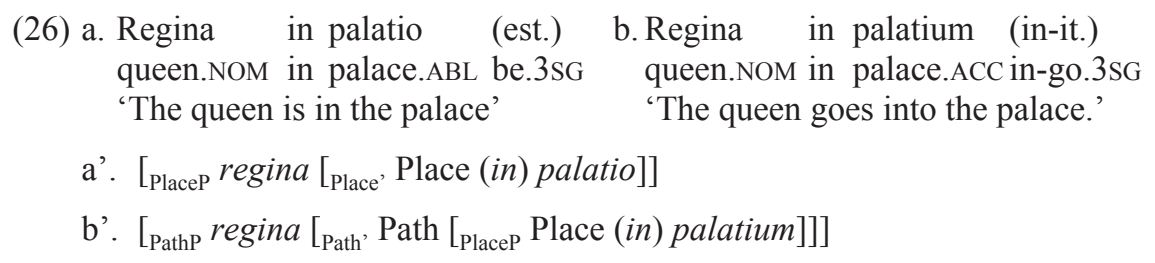

At the core of the present proposal is the assumption concerning the refinement of the syntactic structure of locative PPs carried out by Noonan (2010: 161-195) and Terzi (2010: 196-224). These two authors argue, on the basis of different kinds of evidence, that locative PPs embed an element of nominal nature that in turn embeds the Ground DP/NP — see Wunderlich (1991) for a seminal idea. Thus, Noonan (2010: 163) claims that "place adpositions, even if morphologically simple, involve an abstract nominal category, Place [...]. Place expresses the "region" (Wunderlich 1991) of the location. The ground argument (object of the preposition) is a possessor argument of the place noun in an inalienable possessor-possessum relation with Place." From this perspective the simple prepositions on, in and under in English correspond to the next abstract paraphrases (Noonan 2010: 163):

(27) on the table $=$ AT TOP (of) the table in the house $=$ AT INTERIOR (of) the house under the bed $=$ AT BENEATH (of) the bed 
As pointed out by Noonan herself, there is overt evidence for this nominal category of relational semantics, which she calls Place. Thus, in the next languages, the particular region of the Ground object that expresses the location "on the table" is directly denoted by an overt nominal, whether independent (as in Basque or Japanese) or affixal (as in Spanish): ${ }^{17}$

(28) a. mahai gaine-a-n

table top-DEF-INESS

(Basque)

b. teeburu-no ue-ni

table-GEN top-LOC

(Japanese; Noonan 2010: 164)

c. en-cima de la mesa

at-top of the table

(Spanish)

Since the Ground DP and Noonan's Place are both nominal categories, it is no wonder that languages glue them together with the mechanisms regularly available to combine nominals: composition in Basque, genitive case on the Ground in Japanese and the genitive preposition de 'of' in Spanish. In Latin, among other languages, the dative is yet another strategy to express this inalienable possession relation between the Ground and Noonan's (2010) Place.

Noonan's (2010: 163) abstract paraphrases in (27) conceal the common semantic core of the three prepositions: the nominal category itself. However, it seems important to distinguish this category from the particular spatial relation conveyed by each preposition: "onness" in the case of on, "innerness" in the case of in and "beneathness" in the case of under. In that respect, Terzi (2010:197) remarks that "[Place] appears to denote the physical space surrounding the reference landmark [...]. This physical space becomes narrower when Place is modified by the locative, while it remains less precise when a locative modifier of Place is missing." Thus, this author distinguishes the locative adposition itself from the nominal category Place. ${ }^{18}$ For instance, in (29a) the nominal Place is modified by the locative epano 'on top', an adjective of sorts, while in (29b) an unmodified Place denotes a vague region: ${ }^{19}$

17. See also Lehmann (1998) for interesting observations on the cross-linguistic variation in the realization of spatial regions and, in particular for Latin, in their implementation as adjectives, as in extremum agmen 'the furthest part of the army' or in summo colle 'on the top of the hill'. For reasons of space and relevance for present purposes I cannot deal with this kind of adjectives in this paper.

18. Noonan's (2010) and Terzi's (2010) Place recalls Svenonius's (2006, 2010: 130-131) AxPart, a functional projection situated below what corresponds to Noonan's (2010) and Terzi's (2010) $\mathrm{P}_{\text {LOC }}$ head, and above the Ground DP, a case projection (KP) intervening. However, the distinction between the nominal dimension and the locative modifier, as implemented in Terzi (2010: 197), does not seem to be feasible with AxPart.

19. Observe that Terzi $(2010: 204,207)$ proposes that Place appears embedded in a DP. This is also proposed by Noonan (2010: 164). Furthermore, Terzi (2010: 204, 207) articulates the syntactic relationship between the Place nominal and the Ground DP in the shape of a (S)mall (C)lause. As shown below, I will pursue a simpler analysis. 
(29) Greek; Terzi (2010: 204, 207)
a. epano s-to trapezi on at-the table 'on the table'
b. s-to trapezi at-the table 'at/in/on the table'
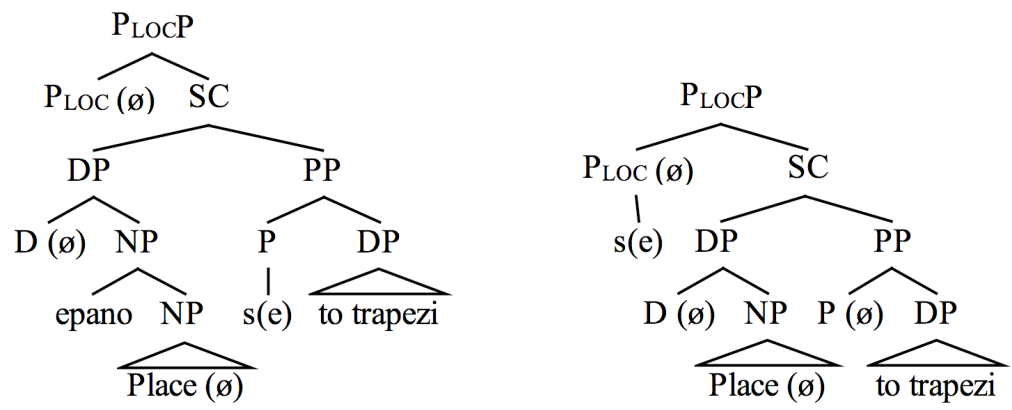

With all the above considerations in mind I present the analysis of a locative PP in Latin. I adopt Noonan's (2010) and Terzi's (2010) abstract nominal category but I call it Locus, in order to distinguish it from the abstract locative preposition Place (in turn equivalent to Noonan's and Terzi's $\mathrm{P}_{\mathrm{LOC}}$ ):

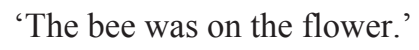

Locus is a null nominal category of relational semantics. It can be modified by an adjoined locative such as super 'on', in which case its denotation corresponds to the upper region of something. Its complement flore 'the flower' is interpreted as the inalienable possessor of that upper region, hence as the Ground. The abstract preposition Place takes LocusP as its complement and maps it onto a location (Svenonius 2010: 131-133). Finally, the DP in Spec-Place, apis 'the bee', is interpreted as the Figure of the spatial relation. A closer paraphrase of the above tree would be "The bee (was) at the on-area of the flower." I take Place to assign ablative case by default to the Ground DP (Compl-Locus). ${ }^{20}$

20. I follow here a similar claim concerning dative case assignment in German locative PPs by Gehrke (2008: 98), who in turn follows van Riemsdijk (2007). 


\subsection{An applicative head below $v$ and above PlaceP}

The last ingredient of my analysis involves the now standard assumption that languages use functional heads called applicatives to add extra arguments to a predicate. Following Pylkkänen (2008: 11-79), to my knowledge the most detailed general theory of applicatives in generative grammar, an applicative head relates an entity with either another entity or an eventuality. The former entity, or applied argument, is the denotation of a DP merged as the specifier of the applicative head. The actual semantic interpretation of the applicative head largely depends on the height at which it is merged in the tree, which in turn seems to be affected by cross-linguistic variation, as Pylkkänen (2008) herself shows.

Cuervo (2003) analyses dative DPs in Spanish from the perspective of the theory of applicatives. I am particularly interested in her proposal of an Aff(ected) Appl(icative head), merged on top of a state-denoting projection, $\mathrm{v}_{\mathrm{BE}} \mathrm{P}$ and relating entities to resultant states of causative or inchoative predicates:

(31) Spanish; Cuervo (2003: 105)

a. Emilio le rompió la radio a Valeria. Emilio DAT.3SG break.PRF.3SG the radio to Valeria 'Emilio broke the radio on Valeria.'

b. A Emilio se le quemaron las tostadas. to Emilio REFL.3PL DAT.3SG burn.PRF.3PL the toast.PL 'The toast burnt on Emilio.'
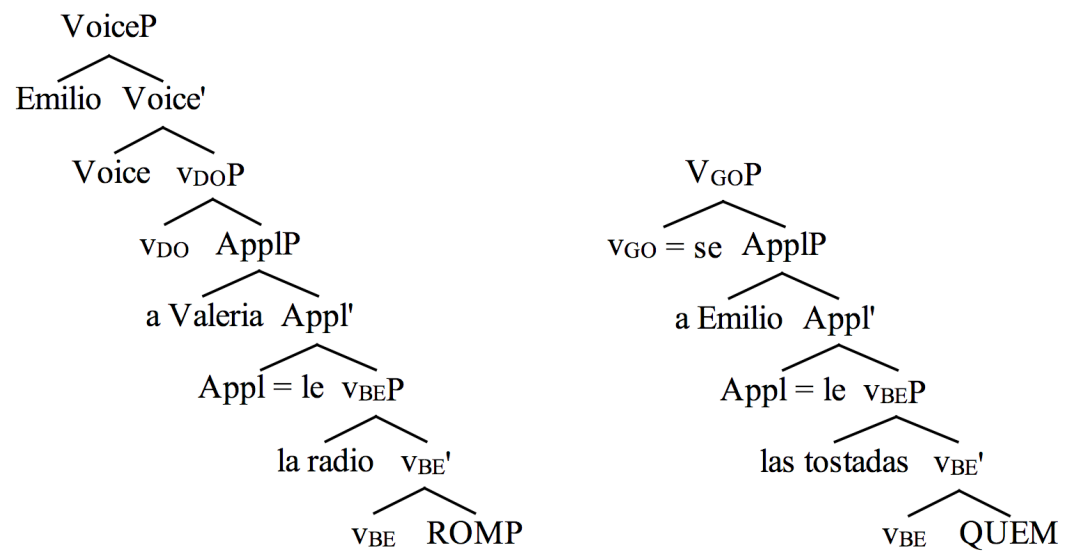

The only difference between the above examples is that the first one is transitive and thereby involves the projection of Voice (Kratzer 1996), introducing the external argument, while the second one is unaccusative. AffAppl, realized as the dative pronoun $l e$ in Spanish, articulates a relation between an affected entity, Valeria and Emilio, respectively, and a state: the state of the radio being broken and the state of the toast being burnt. Those final states in turn involve an abstract 
eventive head of stative semantics, $\mathrm{v}_{\mathrm{BE}}$, taking the verbal root (ROMP 'break', QUEM 'burn') as complement. With respect to the semantic interpretation of AffAppl, Cuervo (2003: 121) specifically proposes that " $[t]$ he dative DP is applied to the end state of the object DP [...]. The dative DP is the 'possessor' of an end state of the object". For instance, in the above examples, Valeria is the "possessor" of the broken state of the radio and Emilio is the "possessor" of the burnt state of the toast. However, Cuervo chooses to formulate the semantics of AffAppl as $\lambda x$. $\lambda e_{\mathrm{s}}$. Affected $\left(\mathrm{e}_{\mathrm{s}}, \mathrm{x}\right), \mathrm{e}_{\mathrm{s}}$ a state. Following claims in McIntyre (2006), I will adhere to the idea that Appl encodes possession, and so I propose the representation $\lambda x$. $\lambda$ es.Possessor $\left(e_{s}, x\right)$. Affectedness would then be an inference licensed when the applied argument is a sentient entity "possessing" a state of affairs rather than another entity (see section 5.1).

Most relevantly for present purposes, Cuervo points out that AffAppl may also be added to predicates denoting events of change of location, in addition to those denoting change of state, as the ones in (31). However, she does not offer an analysis for the part of the tree encoding the resulting location - cf. her notation "XP??" in (32): ${ }^{21}$

(32) A Lucila le puso la mano en-cima. to Lucila DAT.3sG put.PRF.3SG the hand in-top 'He/She put his/her hand on Lucila.'

(Spanish; Cuervo 2003: 159)

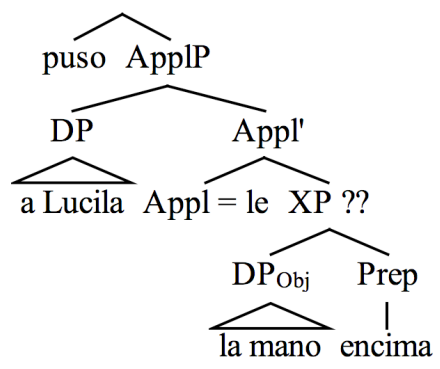

From a localistic perspective (Gruber 1965, Jackendoff 1990), however, it is easy to envisage a solution for Cuervo's (2003: 159) "XP??", since (change of) location and (change of) state are taken to be just two realizations of the same abstract structure. Thus, I follow Hale \& Keyser (1993, 2002), Mateu (2002) and the

21. Sánchez López (2007: 169-171) calls attention upon similar sentences in Spanish:

(i) Ana se le sentó encima.

Ana REFL DAT.3SG sit.PRF.3SG on_top

'Ana sat on top of her/him.'

In an endeavour to reduce this kind of dative to possessive datives in general, this author proposes that the dative in (i) actually originates as an argument of the adverbial encima 'on top' and moves to the specifier position of an extra verbal projection that assigns dative case to it. As is shown below, in my analysis the dative originates directly as the specifier of an applicative head. I thank Cristina Sánchez López for making her work available. 
minimalist implementation in Acedo-Matellán (2016: 41-42) in assuming that the expression of state and that of location involve the same set of abstract heads of adpositional nature. Specifically, Path introduces a transition and Place construes a state/location. Taking that into account, a uniform syntactic analysis for the change of state in example (31b) and the change of location in example (32) seems feasible:22

\section{(33) A unified analysis for change of state and location}

a.

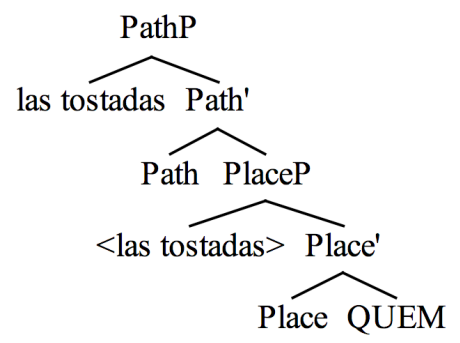

b.

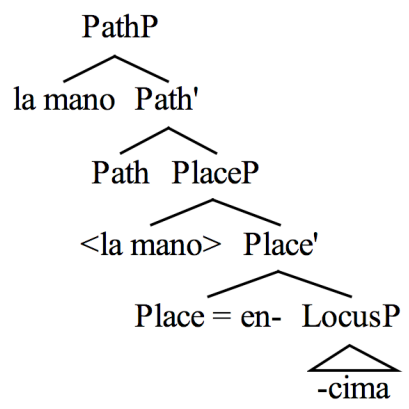

The differences between these representations boil down to semantic and phonological properties of elements in PlaceP; crucially, they are not differences in the functional structure. Place is an abstract predicational relator and is spelled out with a null exponent in (33a) and as $e n$ - in the presence of the Locus affixal noun -cima 'top' in (33b). On the other hand, Compl-Place is the root QUEM 'burn' in the former and a relational noun of locative semantics (-cima) in the latter, which accounts for the interpretation of state vs. location..$^{23}$ Finally, the merger of Path on top of PlaceP semantically maps a state/location onto a resulting or final state/ location.

22. I assume that the Figure argument (las tostadas 'the toast', la mano 'the hand') originates as the specifier of PlaceP and rises to Spec-Path, whenever it is projected. This movement, related to the aspectual interpretation of the predicate, is tangential to the present discussion. See AcedoMatellán (2016: 48-51) for a detailed justification.

23. Moreover, as observed by an anonymous reviewer, the inherently relational status of -cima warrants the interpretation of an inalienable possessor, either overt, or anaphorically or deictically recovered. Thus, if the dative (A Lucia, le) is eliminated in (32) the interpretation is still obligatorily that of having put the hand on top of something. The root QUEM, on the other hand, is not relational. This difference could explain that datives in expressions of change of location with adverbs like encima 'on top' or p-datives in predicates of change of location in Latin, are not optional to the same extent as those accompanying predicates of change of state like those in (31). 


\subsection{Putting everything together}

I now combine the three assumptions previously elaborated on to provide an analysis of p-datives. I consider a transitive predicate ((17), repeated here as (34)), although the analysis and the description would be exactly the same for unaccusative predicates (see (7) or (13)). The only difference is the presence vs absence of an external argument, as introduced by Voice.

(34) Gallinis anitum ova saepe sup-ponimus.

hen.DAT.PL duck.GEN.PL egg.ACC.PL often under-put.1PL

'We often place ducks' eggs beneath the hens.' (Cic. nat. deor. 2, 124)

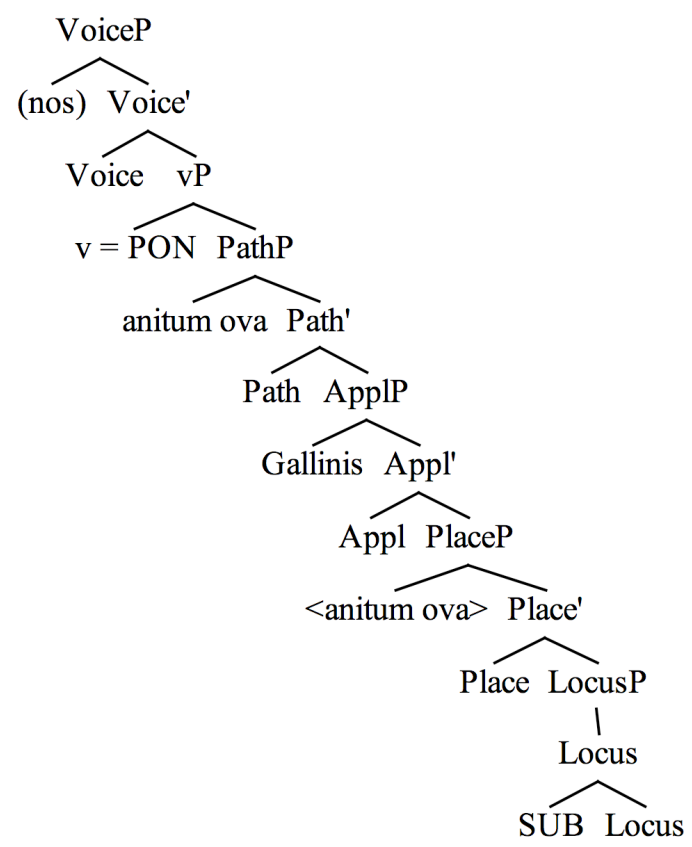

The dative gallinis 'the hens' is introduced as the specifier of an Appl head merged with PlaceP, and receives dative case from this head. The entity denoted by the dative is put in relation to a resulting location codified by PlaceP, namely the location of the 'ducks' eggs' (anitum ova) in "an under region". That "under" region is codified in LocusP: the general denotation of the null relational Locus noun as "region of" is narrowed down to that of "under region of" by virtue of the adjunction of the locative root SUB 'under' (Terzi 2010: 197). The semantics assumed for Appl in section 4.3 ensures that the applied argument is presented as "possessing" the resultant location or state. In this case, the hens (gallinis) "possess" the resultant location of the eggs: it is with respect to the hens that the eggs are placed in an "under region". In particular, the relational semantics inherent to 
Locus are satisfied by the dative DP, which is interpreted as its inalienable possessor. Thus, Serbat's (1996: 443) claim that the preverb denotes a position whose coordinates are furnished by the dative is naturally implemented in this analysis. To make the semantic compositionality of Appl and PlaceP more precise, Appl combines with PlaceP, which denotes a state, via Event Identification (Cuervo 2003: 125, following Pylkkänen 2008: 12 on high applicatives), and with the dative at Spec-Appl via Functional Application, yielding a state again. Path maps this location/state onto a change of location/state:

(35) A (partial) semantic representation of (34)

ApplP $\left[\lambda \mathrm{e}_{\mathrm{s} . P o s s e s s o r}\left(\mathrm{e}_{\mathrm{s}}\right.\right.$, hens $) \&$ “ducks' eggs under”( $\left.\left.\mathrm{e}_{\mathrm{s}}\right)\right]$

Gallinis Appl' [ $\lambda x . \lambda e_{\text {s.Possessor }\left(\mathrm{e}_{\mathrm{s}}, \mathrm{x}\right)}$ \& “ducks' eggs under" $\left.\left(\mathrm{e}_{\mathrm{s}}\right)\right]$

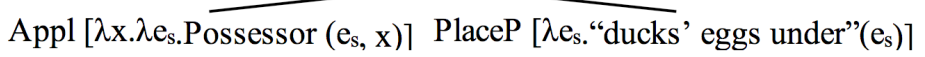
anitum ova Place'

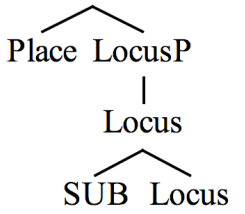

The tree in (34) does not represent, of course, the final form of the sentence. Some operation, either purely phonological, as conflation in Hale \& Keyser (1993, 2002: 60) and Acedo-Matellán (2010: 75-77), or a Raising operation as in AcedoMatellán (2016: 60-62), brings the phonological material corresponding to the locative modifier, SUB, up onto the verb. In combination with the higher functional heads Tense, etc., the prefixed form supponimus is yielded. ${ }^{24}$

\section{Predictions. Extension of the analysis to other datives and to unprefixed verbs}

\subsection{Interpretation of the p-dative}

The Appl head I have proposed puts in relation an entity, denoted by the dative DP in its specifier, and a resulting location/state, denoted by PlaceP. It is by virtue of that semantic relation that the affectedness effect pointed out in section 2, emerges: the resulting location/state is predicated of the Figure argument and, by virtue of Appl, that predication relation can be said to be in turn predicated, as a whole, of the dative DP. The affectedness effect is salient when the dative DP denotes

24. For the movement of the DP anitum ova 'ducks' eggs' from Spec-Place to Spec-Path in (34), see footnote 22. I assume that the applied argument, as a result of (dative) case marking in situ, cannot count as an intervener for this movement. 
an animate being, as shown in the discussion involving examples (5) and (6) in section 2. As pointed out in section 3.2, when the dative denotes an inanimate being the effect ceases to be evident:

(36) Hi duo amnes [...] in-cidunt Oriundi flumini. these.NOM two.NOM river.NOM.PL in-fall.3PL Oriuns.DAT river.DAT 'These two rivers fall into the river Oriuns.' (Liv. 44, 31, 4)

In fact, the difference between animate and inanimate p-datives as regards affectedness is fully expected if the effect is a pragmatic one, and hence not encoded in the lexical entry of the Appl head itself (see section 4.3). It is interesting in this respect to pay attention to McIntyre's (2006: 191) remarks on the semantics of his $\mathrm{V}^{\text {dat }}$, an eventive head that he proposes to be involved in German constructions with datives and in English constructions with predicates like have, get and with, and which could be said to be partially analogous to the Appl head I am now dealing with. In particular, McIntyre observes that $\mathrm{V}^{\text {dat }}$ has an abstract HAVE meaning that relates entities with either entities or situations. In the latter case, and when the applied argument is a sentient being, a felicitous way, and maybe the only one, to make sense of that abstract relation is by positing that the situation (in my case a change of location/state) has somehow affected that entity. When the applied argument is not sentient that interpretation is not available, since non-sentient beings cannot be affected. It is in this way that, for instance, Rubio's (1982: 150) claim that the dative expresses interest can be adequately qualified.

As we have seen, the p-dative is, in addition, interpreted as the inalienable possessor of Locus, an inherently relational noun, which is in turn modified by the locative that will end up prefixed on the verb. From this inalienable possession interpretation emerges the inference that the denotatum of the p-dative is the Ground of the preverb. Thus, regarding the last example above, a close paraphrase like "These two rivers fall to the in-region of the river Oriuns" straightforwardly elicits the readings "These two rivers fall into the river Oriuns". This analysis does not posit, therefore, that the p-dative is the actual semantic Ground or relatum of the preverb, as in Lehmann's (1983) proposal, and so it avoids the problems pointed out in section 3.1.

\subsection{Comparison with the dativus (in)commodi and the dativus sympatheticus}

I have proposed that the particular kind of dative analysed in this work is merged on top of PlaceP. This assumption generates a series of predictions regarding constituency and also the interpretation of nominal expressions located in the scope of the applied argument.

With respect to the former, the prediction is that p-datives should not be able to be stranded in operations substituting a special form for the vP. By contrast, datives merged above the $\mathrm{vP}$, should be able to be stranded in the same circumstances. A candidate for such a kind of dative is the dativus (in)commodi, corresponding to the benefactive/malefactive of the literature on English (cf. 
Pylkkänen's 2008: 17 high dative), and to the mid-benefactive of Devine \& Stephens (2013: 136-137):

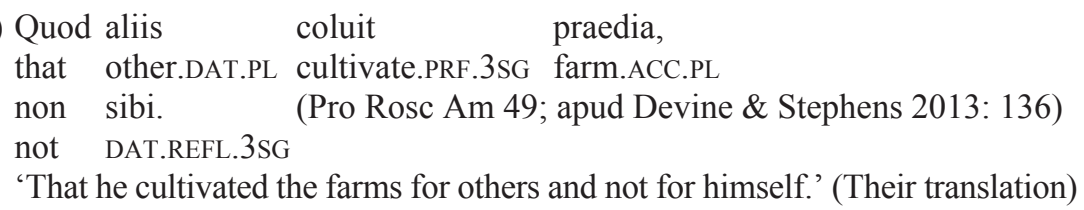

This predicted asymmetry between the p-dative and the dativus (in)commodi obtains, according to Happ's $(1976: 405,407)$ id facio = 'do-so' substitution test illustrated in (21b) and (22b) (section 3.2).

Regarding the second kind of prediction, since the dative is attached above PlaceP, it is expected to be interpretable as the possessor of any relational noun located within this projection. This is what I claim happens in examples such as the following one, involving the so-called dativus sympatheticus (Bennett 1910-1914: 134-145, Havers 1912, Löfstedt 1928-1933: 164-185, Serbat 1996: 563-568):

(38) Mihi paternae uocis sonitus auris ac-cidit. me.DAT father's.GEN voice.GEN sound.NOM ear.ACC.PL at-fall.3SG 'The sound of the father's voice arrives at my ears.' (Plaut. Stich. 88)

As has been repeatedly noted in the literature, mihi 'me' denotes an entity interpreted as the possessor of the ears. This is expected if auris 'ears' is the Ground of the construction, inside PlaceP (specifically, at Compl-Locus), and the dativus sympatheticus is merged somewhere above. On the other hand, Happ's (1976) work suggests that the dativus sympatheticus is merged inside the vP, since, as pointed out by this author, this type of dative cannot be stranded under id facio substitution (Happ 1976: 407). There are then reasons to believe that the dativus sympatheticus with prefixed verbs is identical to the p-dative, casting doubts on classifications such as Bennett's (1910-1914: 132), in which the dativus sympatheticus is grouped together with higher datives like the dativus ethicus. Semantically, moreoever, it also makes sense to consider that this dative is introduced by the same functional head that introduces p-datives. Indeed, the dativus sympatheticus shows affectedness effects not attested in possessor DPs marked with the genitive case, as reported in the literature (see, for instance, Van Langendonck 1998: 217). This asymmetry strikingly parallels that between p-datives and Grounds encoded as PPs (section 2).

\subsection{Kinds of verbs licensing spatial datives. P-datives and directional datives}

The hypothesis that $\mathrm{p}$-datives are introduced by an applicative head relating entities to resulting locations/states predicts that the dative will be found with verbs encoding a resulting state or location, even without a prefix. Consider first verbs of change of state like secare 'cut': 
(39) [M. Mario] vivo et spiranti

M. Marius.DAT alive.DAT and breathing.DAT

collum [secuerit].

neck.ACC cut.PRF.SBJV.3sG

'He cut M. Marius's neck while alive and breathing.' (Q. Cic. pet. 10, 1)

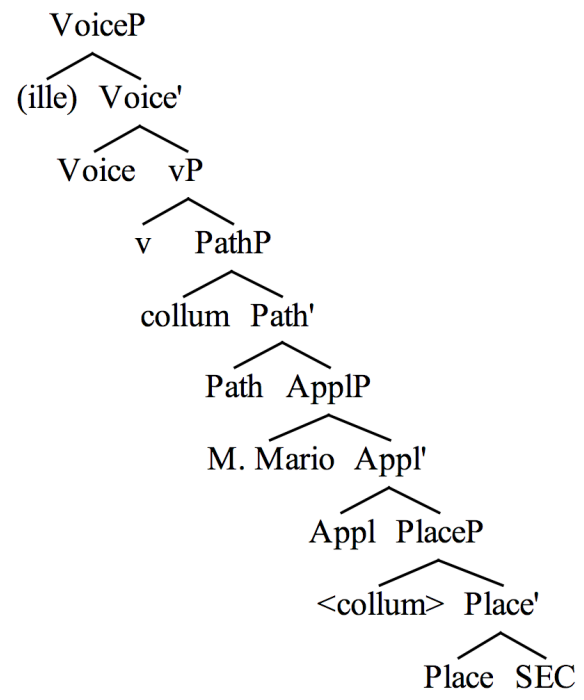

This example is strikingly similar to those Spanish ones used by Cuervo to illustrate the syntax and semantics of her AffAppl head (see section 4.3). This is represented in the above analysis. The Ground is not LocusP but the root of the verb, SEC 'cut', interpreted as the resultant state of the Figure argument collum 'the neck'. The whole is related to the dative M. Mario by the applicative head, so M. Marius is interpreted as being affected by "the neck ending up cut". ${ }^{25}$ Since collum 'the neck' is a noun of inalienable possession, the dative is additionally interpreted as its possessor. ${ }^{26}$ Other unprefixed verbs encoding a change of state

25. Incidentally, this example shows the two depictive secondary predicates vivo 'alive' and spiranti 'breathing', which refer to the dative M. Mario. The fact that the dative may control this type of predicate could be an empirical argument against analysing it as a low-applied argument of the English type, in the sense of Pylkkänen (2008: 14-15), if, as argued by this author, low-applied arguments - i.e., the goal arguments in Double Object Constructions - cannot host depictive secondary predicates:

(i) $*$ I gave Mary $_{i}$ the meat angry ${ }_{i}$.

(Baker 1997, apud Pylkkänen 2008: 21)

26. It seems reasonable to think that datives appearing with stative verbs like dolere 'hurt' or prefixed verbs based on esse 'be' (for instance, ad-esse "at-be", 'be near, by the side'), are amenable to a similar analysis:

(i) $[\mathrm{Ei}]$ genua dolent.

him/her.DAT knee.NOM.PL hurt.3PL

(Cels, 4, 30, 26)

'His/her knees hurt.' $\approx$ “To him/her the knees are in pain.” (Cf. Hale \& Keyser 2002: 208)

The difference with the other predicates we have dealt with is that the state here is not a resulting state - it is thus not embedded under PathP. For reasons of space I cannot go into the details of the analysis of these verbs. 
and admitting a dative argument are miscere 'mix', haerere 'stick' or iungere 'yoke' (Serbat 1996: 455, 459):
(40) $[\mathrm{saxa}]$
mixta
harenae
stone(N)PL mix.PTCP.PST.PASS.NOM.N.PL sand.DAT

'stones mixed with sand'

(Vitr II, 5, 2, apud Serbat 1996: 460)

Unprefixed verbs expressing change of location by themselves are also expected to admit a dative identifying the goal of motion. These directional datives are found with verbs like ire 'go' or venire 'come' (see section 2):

(41)
$\begin{array}{ll}\text { Dum tibi } & \text { litterae } \\ \text { until you.DAT } & \text { LETTER(F }\end{array}$
meae
ueniant.
until you.DAT LETTER(F)NOM.PL my.NOM.F.PL
come.SBJV.3PL

'Until my letter reaches you.'

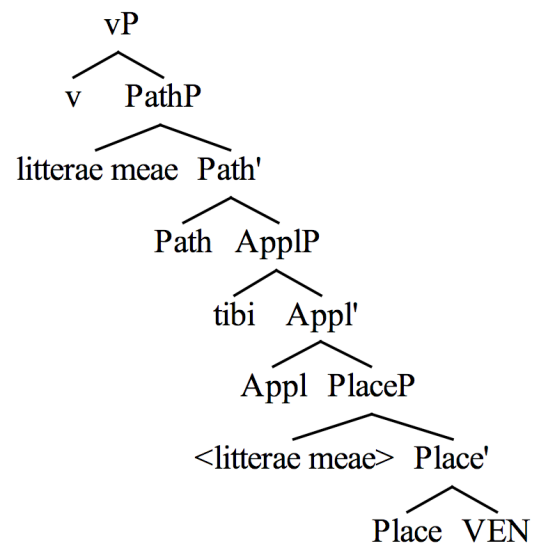

(Cic. fam. 11, 24, 2)

Following ideas in Bouchard (1995), I assume that a verb like venire 'come' corresponds to a Path-Place configuration where the Ground (the root VEN 'come') is a mere deictic. The whole final location of the letter (litterae) is identified with the denotatum of the directional dative tibi 'you'. For sentences headed by ire 'go', like the well-known example It clamor caelo 'The cry went up to heaven' (see (8)), I would posit an unmodified Locus at Compl-Place, rather than any verbal root. My motivation is that predicates headed by cognate go-verbs in languages like Catalan, Occitan or French always require a nominal Ground, either a DP or a pronoun (Cat. $h i$, Occ. $i$, Fr. $y$ ), which suggests that these verbs are actually rootless and lexicalize the whole configuration.

As just seen, the theory presented in this work allows a unification of p-datives and directional datives more generally, unlike views such as Lehmann's (1983) or Rubio's (1982) - see section 3. It moreover allows for a further important prediction: predicates headed by unprefixed manner-of-motion verbs should not allow a directional dative. This is so because such verbs encode an activity rather than a bounded eventuality with a final location. Thus, an unprefixed manner-of-motion 
verb like vagari 'wander' may take a durative adverbial like per aliquot dies 'for some days', since it does not entail any (locative) telos. As shown below, I analyse these verbs as any other unergative verb, with the verbal root being directly merged to the eventive head $\mathrm{v}$ :

(42) Per aliquot dies vagari.

for some day.ACC.PL wander.INF

'To wander for some days'.

[VoiceP $P R O$ [Voice, Voice ${ }_{\mathrm{vP}} \mathrm{V}$ VAG] $\left.]\right]$

(Plin. nat. 17, 209)

Since PlaceP is not projected, there is semantically no state for Appl to be applied to, whence the impossibility of a directional dative. That this prediction is born out is what Serbat's (1996: 506-512) observations suggest. Specifically, he points out that a dative can encode a goal with inherently directional verbs such as venire 'come' or ferre 'bring' (which in my terms would involve the projection of a PathP), but not with manner verbs like trudere 'push' and currere 'run'. As expected, prefixed counterparts of such verbs readily admit the dative interpreted as goal:

(43) Armentis in-currere.

cattle.DAT.PL in-run.INF

'Run against the cattle.'

(Ov. met. 7, 538)

Going beyond Serbat's (1996) observation, I do not expect predicates headed by an unprefixed manner-of-motion verbs to license a dativus sympatheticus either, even if a directional PP identifying a final location is involved in the construction. Thus, although I have not conducted any corpus search, I claim that an invented example such as the next one, involving a dativus sympatheticus of sorts, should not be possible:

(44) *Mihi equitauit ad portas. me.DAT ride.PRF.3SG at door.ACC.PL

(Invented example) Int.: 'She/He rode up to my doors.'

I will now expose the reasoning underlying this more speculative claim. According to Acedo-Matellán (2016: 175), in languages like Latin, unlike in Germanic languages, a directional PP does not suffice to license the interpretation of a resulting location/state with a manner-of-motion verb. In Acedo-Matellán (2016: 177) I propose that this is because Latin — and Ancient Greek and Slavicalthough allowing the expression of manner and of resulting location/state in different morphs, requires that both morphs end up forming one word, as shown in prefixed manner-of-motion verbs like in-currere "in-run". In the theory presented here that means that the phonological material in the heads structuring a changeof-location/state event has to be brought onto the eventive head (see section 4.1). With that in mind, it is easy to understand why an example such as (44) could not 
be interpreted as involving a resulting location (PlaceP, under PathP), indirectly licensing the dative mihi 'me'. If (44) involved a PathP embedded under v, the locative $\mathrm{AD}$ 'at', merged as an adjunct to Locus, would obligatorily end up prefixed onto the verb, as in the following example from Livy, which effectively hosts the p-dative portis 'the doors':

(45) Ad-equitauit portis. at-ride.PRF.3SG door.DAT.PL

'He rode up to the doors.'

The only available interpretation for equitavit ad portas is, thus, that in which the verb expresses an activity rather than a telic eventuality, and the PP denotes an unbounded path: 'she/he rode towards the doors' ${ }^{27}$ The verb would then receive the analysis of unergatives (see (42)) and the PP would be merged with the $\mathrm{vP}$, as an adjunct. However, as we saw above, predicates of this kind do not license directional datives, since they do not entail a (resulting) location/state. ${ }^{28}$

\section{Conclusions and remaining issues}

In this paper I have dealt, primarily, with the syntax and semantics of p-datives, those dative DPs that appear with a prefixed verb in Latin and that are interpreted as the Ground of the preverb. I have presented and discarded the two main previous accounts: the one in which the dative realizes one of the arguments of the preverb itself and the one in which it is a sort of dativus (in) commodi.

I have proposed an explicitly configurational approach in which the p-dative is introduced as the specifier of an applicative head relating entities with resultant states/locations. This head is merged within the $\mathrm{vP}$, above the projection

27. See van der Heyde (1934) for an early similar observation on the difference between prefixed motion verbs and unprefixed motion verbs with directional PPs.

28. Interestingly, similar effects are found in Romance languages that use datives in motion constructions. As is well known (Talmy 2000, Mateu \& Rigau 2002, Acedo-Matellán \& Mateu 2015: 99-122), in these languages the trajectory and final location of a motion event is obligatorily expressed in the verbal root. Manner-of-motion verbs do not license a resulting location interpretation, even when accompanied with a directional PP. From the perspective adopted here, a dative can be used with verbs incorporating the final location, as Catalan arribar 'arrive', but not with manner-of-motion verbs like Catalan flotar 'float'. This prediction seems to be born out — see Sánchez López (2007: 170) for a similar contrast in Spanish:

(i) Catalan; (setting: a rubber ball is floating on the sea and is slowly coming to the shore, where I stand)

a. La pilota de goma em va arribar als peus (flotant). the ball of rubber me.DAT PST arrive.INF at=the.PL feet (floating) 'The rubber ball reached my feet (floating).'

b. *La pilota de goma em va flotar (cap als peus). the ball of rubber me.DAT PST float.INF (towards at=the.PL feet)

'The rubber ball floated (towards the/*my feet).'

The difference between Catalan and Latin is that the latter does allow directional datives/dativi sympathetici with manner-of-motion verbs, on the condition that they are prefixed. 
expressing location/state: PlaceP. A PathP projection above ApplP forces a resultant location/state interpretation of PlaceP. Following recent proposals on the structure of locative PPs, I have put forth that PlaceP embeds a null nominal of relational semantics, Locus, denoting the region occupied by the Ground object. In turn, the preverb is originated as a modifier of Locus. The dative introduced by the applicative head (and assigned case by it) is interpreted as being related to the whole predicative relation established in PlaceP, whence the affectedness effect linked to the p-dative; additionally it is interpreted as the possessor of Locus. The interpretation of the dative as the Ground of the preverb is but an inference of this inalienable possession relation between it and the nominal Locus, as modified by the preverb.

I have explored a series of predictions following from the analysis proposed. The attachment site of the p-dative, below $\mathrm{v}$, distinguishes these datives from benefactive/malefactive datives, and brings them together with the dativus sympatheticus, pace part of the literature. The fact that the p-dative is introduced by an applicative head that targets resultant states/locations makes us expect that similar datives are possible with unprefixed verbs encoding those notions, that is, unprefixed change-of-state verbs like secare 'cut' and verbs of directed motion like veni$r e$ 'come' or ferre 'bring'. The prediction has been shown to be born out, which, in the latter case, provides us with the welcome result of unifying p-datives and directional datives. Additionally, unprefixed verbs of manner of motion, which do not codify a resultant location, have been felicitously predicted to disallow directional datives. In a more speculative vein, I have hypothesized that that disallowance obtains even when the unprefixed manner-of-motion verb is accompanied by a directional PP, on the grounds of independent morphological properties of Latin explored in depth in Acedo-Matellán (2016).

Future research must address the empirical exploration of this last prediction, as well as the asymmetry among preverbs with respect to the frequency in their selection of p-datives (Lease 1912, Lehmann 1983).

\section{References}

Acedo-Matellán, Víctor. 2006. Prefixes in Latin and Romance and the satellite- vs. verb-framed distinction. Universitat de Barcelona (ed.), Actes del VII Congrés de Lingüistica General (CD-ROM). Barcelona: Publicacions i Edicions de la Universitat de Barcelona.

Acedo-Matellán, Víctor. 2010. Argument Structure and the Syntax-Morphology Interface. A Case Study in Latin and other Languages. PhD dissertation, Universitat de Barcelona. Downloadable at <http://diposit.ub.edu/dspace/handle/2445/42060> (February 2017).

Acedo-Matellán, Víctor. 2016. The Morphosyntax of Transitions. A Case Study in Latin and Other Languages. Oxford: Oxford University Press.

$<$ https://doi.org/10.1093/acprof:oso/9780198733287.001.0001>

Acedo-Matellán, Víctor \& Mateu, Jaume. 2015. Parameters and argument structure I: Motion predicates and resultatives. In Fábregas, Antonio; Mateu, Jaume \& 
Putnam, Michael. (eds.). Contemporary Linguistic Parameters, 99-112. London: Bloomsbury.

Baker, Mark C. 1997. Thematic roles and syntactic structure. In Haegeman, Liliane (ed.). Elements of grammar: Handbook of generative syntax, 73-137. Dordrecht: Kluwer.

$<$ https://doi.org/10.1007/978-94-011-5420-8_2>

Baños Baños, José Miguel. 2009. VII. Dativo. In Baños Baños, José Miguel (coord.). Sintaxis del latín clásico, 185-209. Madrid: Liceus.

Bennett, Charles. E. 1910-1914. Syntax of early latin. Boston: Allyn \& Bacon.

Bibliotheca Teubneriana Latina Online. 2009. Berlin \& Boston: De Gruyter. <http:// www.degruyter.com/view/db/btl> (February 2017).

Biskup, Petr. 2009. Prefixes as Prepositions and Multiple Cases. In Zybatow, Gerhild; Biskup, Petr; Junghanns, Uwe \& Lenertová, Denisa (eds.). Studies in Formal Slavic Phonology, Morphology, Syntax, Semantics and Information Structure, 3-17. Bern: Peter Lang.

Bonelli, Guido. 1983. Dativo direzionale e significato delle funzioni sintattiche. Latomus 42: 863-868.

Bouchard, Denis. 1995. The Semantics of Syntax: A minimalist approach to grammar. Chicago: University of Chicago Press.

Cabrillana, Concepción. 1997a. Expresión casual de complementos de Venio y Eo. Habis 28: 325-336. Downloadable at <http://institucional.us.es/revistas/ habis/28/26\%20cabrillana\%20leal.pdf> (February 2017).

Cabrillana, Concepción. 1997b. Complementos direccionales en el marco predicativo de Venio. Minerva 11: 117-137.

Calboli, Gualtiero. 2009. Latin syntax and Greek. In Baldi, Philip \& Cuzzolin, Pierluigi (eds.). New Perspectives on Historical Latin Syntax, vol. i: Syntax of the Sentence, 65-193. Berlin \& New York: Mouton de Gruyter. $<$ https://doi.org/10.1515/9783110205626.65>

Colucci, Loris. 1981. Prospettive per una reinterpretazione del dativo in Virgilio. Roma: Angelo Signorelli.

Cuervo, $\mathrm{M}^{\mathrm{a}}$ Cristina. 2003. Datives at Large. PhD dissertation, Massachussets Institute of Technology. Downloadable at $<\mathrm{http}$ ://www.ai.mit.edu/projects/dm/theses/cuer vo03.pdf> (February 2017).

Demonte, Violeta. 1995. Dative alternation in Spanish. Probus 7: 5-30. $<$ https://doi.org/10.1515/prbs.1995.7.1.5>

Devine, Andrew M. \& Stephens, Laurence D. 2013. Semantics for Latin: An introduction. Oxford \& New York: Oxford University Press.

Dikken, Marcel den. 2010. On the functional structure of locative and directional PPs. In Cinque, Guglielmo \& Rizzi, Luigi (eds.). The Cartography of Syntactic Structures, vol. vi: Mapping Spatial PPs, 74-126. Oxford: Oxford University Press. $<$ https://doi.org/10.1093/acprof:oso/9780195393675.003.0003>

Echarte, Ma José. 1994. Sobre el valor del dativo en latín. El llamado dativo de dirección y el dativo con verbos prefijados. Minerva 8: 211-241.

Emonds, Joseph. 1972. Evidence that indirect object movement is a structure preserving rule. Foundations of Language 8: 546-561.

Ernout, Alfred \& Thomas, François. 1964. Syntaxe latine. Paris: Librairie C. Klincksieck. 
Fay, Edwin W. 1911. The Latin Dative: Nomenclature and Classification. Classical Quaterly 5: 185-195.

$<$ https://doi.org/10.1017/S0009838800019601>

García Hernández, Benjamín. 1986. Gramática de casos y disociación intrasubjetiva: dativo profundo y dativo funcional. Cuadernos de Filología Clásica 20: 231-248. Downloadable at $<$ https://revistas.ucm.es/index.php/CFCA/article/download/ CFCA8687110231A/3115> (February 2017).

García Hernández, Benjamín. 1995. El dativo latino. Funciones e interferencias sintácticas y semánticas. In Torrego, $\mathrm{M}^{\mathrm{a}}$ Esperanza; Quetglas, Pere J. \& Espinilla, Empar. (eds.). Sintaxis del dativo latino, 35-49. Barcelona: Publicacions i Edicions de la Universitat de Barcelona.

Gehrke, Berit. 2008. Ps in Motion: On the Semantics and Syntax of P Elements and Motion Events. Utrecht: LOT Publications. Downloadable at $<$ http://dspace.library. uu.nl/bitstream/handle/1874/29301/gehrke.pdf?sequence=1 $>$ (February 2017).

Gruber, Jeffrey S. 1965. Studies in lexical relations. PhD dissertation, Massachusetts Institute of Technology. Downloadable at $<$ http://www.ai.mit.edu/projects/dm/theses/gruber65.pdf> (February 2017)

Gustafsson, Fridolf. 1904. De dativo latino. Helsinki: Weillin \& Gööds.

Gutiérrez Galindo, Marco Antonio. 1995. Sintaxis, semántica y pragmática del dativo de dirección en latín. In Torrego, $\mathrm{M}^{\mathrm{a}}$ Esperanza; Quetglas, Pere J. \& Espinilla, Empar. (eds.). Sintaxis del dativo latino, 51-60. Barcelona: Publicacions i Edicions de la Universitat de Barcelona.

Gutiérrez Galindo, Marco Antonio. 2004. El dativo latino: interpretaciones y bibliografía en los dos últimos siglos. Emerita 72: 301-350. $<$ https://doi.org/10.3989/emerita.2004.v72.i2.70>

Hale, Kenneth \& Keyser, Samuel J. 1993. On argument structure and the lexical expression of syntactic relations. In Hale, Kenneth \& Keyser, Samuel J. (eds.). The View from Building 20: Essays in Linguistics in Honor of Sylvain Bromberger, 53-109. Cambridge (Massachusetts): MIT Press.

Hale, Kenneth \& Keyser, Samuel J. 2002. Prolegomenon to a Theory of Argument Structure. Cambridge (Massachusetts): MIT Press.

Happ, Heinz. 1976. Grundfragen einer Dependenz-Grammatik des Lateinischen. Göttingen: Vandenhoeck \& Ruprecht.

Havers, Wilhelm. 1912. Dativus sympatheticus. Bulletin de la Société de linguistique de Paris 18: 34.

Heyde, Klaas van der. 1934. L'aspect verbal en latin. Problèmes et résultats. Le rôle du préverbe. Revue des études latines 12: 140-157.

Hofmann, Johann B. \& Szantyr, Anton. 1965. Lateinische Syntax und Stilistik. München: Beck.

Jackendoff, Ray. 1983. Semantics and Cognition. Cambridge (Massachusetts): MIT Press.

Jackendoff, Ray. 1990. Semantic Structures. Cambridge (Massachusetts): MIT Press.

Kayne, Richard S. 1985. Principles of particle constructions. In Guéron, Jacqueline; Obenauer, Hans-Georg \& Pollock, Jean-Yves (eds.). Grammatical Representation, 101-40. Dordrecht: Foris.

Koopman, Hilda J. 2000. The Syntax of Specifiers and Heads. Collected Essays of Hilda J. Koopman. London \& New York: Routledge. 
Kratzer, Angelika. 1996. Severing the external argument from its verb. In Rooryck, Johan \& Zaring, Laurie (eds.). Phrase Structure and the Lexicon, 109-137. Dordrecht: Kluwer. $<$ https://doi.org/10.1007/978-94-015-8617-7_5>

Kühner, Raphael \& Stegmann, Carl. 1912. Ausführliche Grammatik der lateinischen Sprache, vol. ii: Satzlehre. Hannover: Hahnsche Buchhandlung.

Lease, Emory B. 1912. The dative with prepositional compounds. American Journal of Philology 33: 285-300. $<$ https://doi.org/10.2307/288996>

Lehmann, Christian. 1983. Latin preverbs and cases. In Pinkster, Harm (ed.). Latin Linguistics and Linguistic Theory. Proceedings of the 1st International Colloquium on Latin Linguistics. Amsterdam, April 1981, 145-165. Amsterdam \& Philadelphia: John Benjamins. $<$ https://doi.org/10.1075/slcs.12.15leh>

Lehmann, Christian. 1998. Regiones espaciales en perspectiva tipológica. In GarcíaHernández, Benjamín (ed.). Estudios de lingüística latina. Actas del IX Coloquio Internacional de Lingüística Latina, Universidad Autónoma de Madrid, 14-18. Madrid: Ediciones Clásicas.

Löfstedt, Einar. 1928-1933. Syntactica. Studien und Beiträge zur historischen Syntax des Lateins, vol. i: Über Einige grundfragen der lateinischne Nominalsyntax. Lund: Gleerup.

Mateu, Jaume. 2002. Argument Structure: Relational Construal at the Syntax-Semantics Interface. $\mathrm{PhD}$ dissertaton, Universitat Autònoma de Barcelona. Downloadable at $<$ http://www.tdx.cat/handle/10803/4828> (February 2017).

Mateu, Jaume \& Rigau, Gemma. 2002. A minimalist account of conflation processes: Parametric variation at the lexicon-syntax interface. In Alexiadou, Artemis (ed.). Theoretical Approaches to Universals, 211-236. Amsterdam \& Philadelphia: John Benjamins. $<$ https://doi.org/10.1075/la.49.09mat>

McIntyre, Andrew. 2006. The interpretation of German datives and English have. In Hole, Daniel; Meinunger, André \& Abraham, Werner (eds.). Datives and other Cases, 185-211. Amsterdam \& Philadelphia: John Benjamins. $<$ https://doi.org/10.1075/slcs.75.09mci>

Miller, D. Gary. 1993. Complex Verb Formation. Amsterdam \& Philadelphia: John Benjamins. $<$ https://doi.org/10.1075/cilt.95>

Murru, Furrio. 1978. Alcune questioni filologico-linguistiche a proposito dell'octavus casus. Glotta 56: 144-155.

Noonan, Máire. 2010. Á to zu. In Cinque, Guglielmo \& Rizzi, Luigi (eds). The Cartography of Syntactic Structures, vol. vi: Mapping Spatial PPs, 161-195. Oxford: Oxford University Press. $<$ https://doi.org/10.1093/acprof:oso/9780195393675.003.0005>

Nutting, Herbert C. 1921. The dative with certain compound verbs. The Classical Journal 16: 368-369.

Olsen, Susan. 1997. Der Dativ bei Partikelverben. In Dürscheid, Christa; Ramers, KarlHeinz \& Schwarz, Monika (eds.). Festschrift für Heinz Vater, 307-328. Tübingen: Niemeyer. 
Oniga, Renato. 2005. Composition et préverbation en Latin: problemes de typologie. In Moussy, Claude (ed.). La composition et la préverbation en latin, 211-227. Paris: Université Paris-Sorbonne.

Oya, Toshiaki. 2009. Ground arguments in German particle verbs: A comparison with Dutch and English. Journal of Germanic Linguistics 21: 257-296. <https://doi.org/10.1017/S1470542709990018>

Pfister, Raimund. 1983. Kompetenz in der lateinischen Syntax. In Pinkster, Harm (ed.). Latin Linguistics and Linguistic Theory. Proceedings of the 1st International Colloquium on Latin Linguistics. Amsterdam, April 1981, 3-8. Amsterdam \& Philadelphia: John Benjamins. $<$ https://doi.org/10.1075/slcs.12.04pfi>

Pinkster, Harm. 1988. Non-accusative second arguments of two-place verbs in Latin. Cuadernos de Filologia Clásica 21: 235-245. Downloadable at $<$ http://revistas.ucm. es/index.php/CFCA/article/download/CFCA8888110235A/3077> (February 2017).

Pinkster, Harm. 2011. The use of the dative with Latin compounds. STUF-Language Typology and Universals / Sprachtypologie und Universalienforschung 64: 126135. $<$ https://doi.org/10.1524/stuf.2011.0011>

Pinkster, Harm. 2015. The Oxford Latin Syntax, vol. i: The Simple Clause. Oxford: Oxford University Press.

$<$ https://doi.org/10.1093/acprof:oso/9780199283613.001.0001>

Pylkkänen, Liina. 2008. Introducing Arguments. Cambridge (Massachusetts): MIT Press. $<$ https://doi.org/10.7551/mitpress/9780262162548.001.0001>

Riemsdijk, Henk van. 2007. Case in spatial adpositional phrases: The dative-accusative alternation in German. In Alboiu, Gabriela; Avram, Andrei; Avram, Larisa \& Isac, Dana (ed). Pitar Mos: A Building with a View. Papers in Honour of Alexandra Cornilescu, 1-23. Bucharest: Bucharest University.

Rubenbauer, Hans \& Hofmann, Johann. B. 1995. Lateinische Grammatik. Bamberg: Buchner.

Rubio, Lisardo. 1982. Introducción a la sintaxis structural del latín. Ariel: Barcelona.

Sánchez López, Cristina. 2007. The possessive dative and the syntax of affected arguments. Cuadernos de lingüistica del I. U. I. Ortega y Gasset 14: 153-173.

Scherer, Anton. 1975. Handbuch der lateinischen Syntax. Heidelberg: Winter.

Serbat, Guy. 1996. Grammaire fondamentale du latin. Tome VI. L'emploi des cas en latin, vol. i: Nominatif, Vocatif, Accusatif, Génitif, Datif. Louvain-la-Neuve \& Paris: Peeters.

Spencer, Andrew \& Zaretskaya, Marina. 1998. Verb prefixation in Russian as lexical subordination. Linguistics 36: 1-39.

$<$ https://doi.org/10.1515/ling.1998.36.1.1>

Svenonius, Peter. 2003. Limits on P: Filling in holes vs. falling in holes. Nordlyd 31: $431-445$. $<$ https://doi.org/10.7557/12.13>

Svenonius, Peter. 2004. Slavic prefixes inside and outside VP. Nordlyd 32: 205-253. $<$ https://doi.org/10.7557/12.68>

Svenonius, Peter. 2006. The Emergence of Axial Parts. Nordlyd 33: 49-77. $<$ https://doi.org/10.7557/12.85> 
Svenonius, Peter. 2007. Adpositions, particles and the arguments they introduce. In Reuland, Eric; Bhattacharya, Tanmoy \& Spathas, Giorgos (eds.). Argument Structure, 63-103. Amsterdam \& Philadelphia: John Benjamins. $<$ https://doi.org/10.1075/la.108.08sve>

Svenonius, Peter. 2010. Spatial P in English. In Cinque, Guglielmo \& Rizzi, Luigi (eds.). The Cartography of Syntactic Structures, vol. vi: Mapping Spatial PPs, 127-160. Oxford: Oxford University Press.

$<$ https://doi.org/10.1093/acprof:oso/9780195393675.003.0004>

Talmy, Leonard. 1978. Figure and Ground in Complex Sentences. In Greenberg, Joseph H. (ed.). Universals of Human Language, 625-649. Stanford (California): Stanford University Press.

$<$ https://doi.org/10.3765/bls.v1i0.2322>

Talmy, Leonard. 2000. Toward a Cognitive Semantics, vol. ii: Typology and Process in Concept Structuring. Cambridge, Massachusetts: MIT Press.

Terzi, Arhonto. 2007. Locative Prepositions, Predicate Inversion, and Full Interpretation. In Agathopoulou, Eleni; Dimitrakopoulou, Maria \& Papadopoulou, Despina (eds.). Selected Papers from the 17th International Symposium on Theoretical and Applied Linguistics, 210-219. Thessaloniki: University of Thessaloniki.

Terzi, Arhonto. 2010. Locative prepositions and Place. In Cinque, Guglielmo \& Rizzi, Luigi (eds.). The Cartography of Syntactic Structures, vol. vi: Mapping Spatial PPs, 196-224. Oxford: Oxford University Press.

$<$ https://doi.org/10.1093/acprof:oso/9780195393675.003.0006>

Théoret, Michel. 1982. Les discours de Cicéron. La concurrence du tour casuel et du tour prépositionnel. Montréal: Université de Montréal.

Touratier, Christian. 1994. Syntaxe latine. Louvain-la-Neuve: Peeters.

Van Hoecke, Willy. 1996. The Latin dative. In Van Belle, William \& Van Langendonck, Willy (eds.). The Dative, vol. i: Descriptive Studies, 3-38. Amsterdam \& Philadelphia: John Benjamins.

$<$ https://doi.org/10.1075/cagral.2.04hoe $>$

Van Langendonck, Willy. 1998. The dative in Latin and the indirect object in Dutch. In Van Langendock, Willy \& Van Belle, William (eds.). The Dative, vol. ii: Theoretical and contrastive studies, 211-259. Amsterdam \& Philadelphia: John Benjamins. $<$ https://doi.org/10.1075/cagral.3.09van>

Woodcock, Eric C. 1959. A new Latin Syntax. London: Methuen.

Wunderlich, Dieter. 1991. How Do Prepositional Phrases Fit into Compositional Syntax and Semantics? Linguistics 29: 591-621.

$<$ https://doi.org/10.1515/ling.1991.29.4.591> 
